\title{
Political Conversations in the United States: Who Talk to Whom, Why, and Why Not
}

Stephen Earl Bennett, Bonnie Fisher, and David Resnick, University of Cincinnati

Although normative political theorists have argued that citizens talking with other citizens about public affairs is essential in a democracy, empirically oriented political scientists have tended to ignore political discussions. This paper draws on National Election Studies and General Social Surveys to plumb the extent and breadth of political conversations in the U.S. We also explore who talks about public affairs, with whom they speak, and why some people avoid discussing politics. A logit analysis of pooled National Election Studies from 1984 to 1992 shows that some factors typically thought to affect taking part in politics are not significant predictors of the probability that people will engage in political discussions, but other variables not normally included in participation models do affect talking about politics.

\section{Introduction}

Democratic theorists have claimed that citizens talking to one another about public affairs is essential to democracy (Dewey 1927; Mansbridge 1983; Mill [1861] 1958, [1859] 1978). Empirically oriented scholars have largely ignored this important mode of involvement in American democracy, ${ }^{1}$ probably because they define and measure political participation in terms of citizens trying to influence government. Hence, we know little about the frequency of political discussions, who talks, with whom they speak, why some people eschew political conversations, what affects the likelihood of talking about public affairs, and what it does for the individual or the political system.

This is a study of political conversations in the U.S. The paper fills several lacunae in our understanding of Americans' involvement in the public life of their society. Engaging in political conversations is a distinct mode of participation in public affairs, apart from conventionally studied activities such as voting, contacting public officials, and even trying to influence how others vote in national elections. Focusing on political conversations significantly alters descriptions of how much political participation occurs in the

STEPHEN EARL BENNETT is Professor of Political Science at the University of Cincinnati. BONNIE FISHER is Associate Professor of Political Science at the University of Cincinnati. DAVID RESNICK is Associate Professor of Political Science at the University of Cincinnati.

The American Review of Politics, Vol. 16, Fall, 1995: 277-298

๑1995 The American Review of Politics 
U.S. If we add political conversations to the list of acts considered as participation, we find that voting is not the only political activity undertaken by more than half the public. In addition, although voters go to the polls only occasionally during a quadrennial cycle, those who engage in political discussions typically do so far more often. More important, adding political conversations to the repertoire of activities probed by students of participation diversifies the makeup of participants. The usual class and racial biases that characterize voting and other forms of political participation are much less apparent when we look at political discussions. Finally, talking about politics appears to enhance taking part in other modes of political participation (Kenny 1993a).

Most of the data come from the University of Michigan's Center for Political Studies' National Election Studies, particularly those from 1984 to 1992. We also use the University of Chicago's National Opinion Research Center's American data from the Five Nation Study, the 1967 Political Participation in America Study, and the 1987 General Social Survey. ${ }^{2}$

The first section of the paper identifies how scholars define political participation, and shows why that definition leads them to ignore political discussions. The second section shows why democratic theorists believed that talking about politics was essential to democracy. We then use data from National Election Studies to describe how often Americans talk about politics and public affairs. The fourth section draws on the 1987 General Social Survey and the 1967 Political Participation in America Study to determine if engaging in political discussions is a distinct mode of political participation. Section five uses the 1987 GSS to explore with whom Americans talk about politics. Section six is a brief analysis of the reasons Americans have given for eschewing political discussions. The seventh section presents a multivariate analysis of why Americans have had a recent political discussion. The conclusion summarizes the paper and identifies a research agenda.

\section{Definitions of Political Participation}

Researchers usually define political participation as activities freely undertaken by private citizens in order to influence government personnel and/or policies (see, e.g., Conway 1991, 31-32; Verba and Nie 1972, 3). Participation does not include activities by which citizens either implement policies (an exception is Parry, Moyser and Day 1993), or interact with other citizens.

Restricting political participation to behavior intended to influence the government divides the community into two distinct categories: citizens and 
the government. It makes political life a process of citizens trying to get government to do their bidding. An older conception of democracy envisioned citizens as the government; citizens' participation in political life was fundamental. This is, as Dryzek $(1988,714)$ noted, the "classical" tradition, which "defines politics in terms of public debate among people deciding how they shall act and interact . . ." (see also Aristotle 1988). Even if modern government must remain representative government, we need to revive some of the older understanding of democracy.

There are numerous activities which are slighted by the current approach to defining political participation. These include actions in which citizens interact with each other, discussing political issues. People talk to influence their family and friends (Huckfeldt and Sprague 1995; Kenny 1993b). Discussion helps clarify political values and attitudes as well as articulate alternative positions. Lane $(1965,80)$ believed that political "discussion serves to anchor each man's opinion in the culture of his life station. It is a form of reality testing. Without it public opinion tends to be hallucinatory, bloodless, and inoperative." As MacKuen put it $(1990,60)$, "the act of public expression itself transforms subconscious sentiments into conscious cognition and provides the basis for an active rather than a passive political involvement." To talk with others about politics is to participate in the political life of one's community or nation.

\section{Participation, Communication, and Community}

Taking part in political discussions is thought to have positive effects on citizens which could not be achieved without participation (Aristotle 1988; Dewey 1927; Mansbridge 1983; Mill [1861] 1958, [1859] 1978). Talking about politics is said to deepen and enrich democracy by enhancing the quality of public life and contributing to civic-mindedness among the people.

John Stuart Mill advocated extending the scope of democratic politics to those excluded in the England of his day. Mill claimed that political debate and discussion help create a wider and deeper community ([1861] 1958; see also Farr, 1993; Kinder and Herzog 1993). Mill also believed there are intellectual and moral benefits from political conversations. For him, unlike many later liberals, these benefits are not the effects of the masses' demands for better public policies. Mill argued that political conversations with other citizens broaden horizons, develop the intellect, and elevate moral sensibilities. Since the only way an individual can learn all there is to know about a subject is by conversing with others, Mill opposed any limits on freedom of thought and expression ([1859] 1978). 
Mill maintained that the moral benefits of political discussion are even more salutary than the educational ([1861] 1958). Exchanging opinions with others exposes one to experiences which promote the development of a more sophisticated moral point of view. The morally backward citizen will also have the opportunity of learning from her or his more enlightened compatriots.

John Dewey was particularly determined to refute critics who felt that the people were unfit for democracy. His answer in a way is similar to Mill's: we must create a community of participant citizens. For Dewey it was communication which was at the heart of the creation of both individual human beings and a human community $(1927,155)$.

Communication is the key to moral and intellectual development within the context of a community (Dewey 1927, 152). Knowledge must not simply be discovered or learned, but used and communicated to solve social problems arising from the consequences of interdependent activities. Dewey insisted that communication technology can never replace the older forms of human communication. "In its deepest and richest sense a community must always remain a matter of face-to-face intercourse" (Dewey 1927, 211). Thus he was a champion of reconstructing local communities.

Dewey's insistence on local communities rests in no small part on his theory of democratic communication, a form of horizontal, intimate, direct speech between citizens. It performs a function which cannot be performed by vertical communications by elites directed towards the masses or by citizens trying to influence government. Dewey asserted that participation in the community in the form of speech increases the intelligence of the citizenry. Conversation among citizens is what creates community, and it is a type of behavior which is so fundamental to democracy and its politics that it is surprising that it is so often ignored by contemporary participation scholars.

\section{Talking about Politics in the U.S.}

One of the first times a pollster probed political conversations was in February, 1941, when the Gallup Poll asked, "[i]n general, what subjects do you think are most often talked about among your friends and acquaintances these days?" (Cantril and Strunk 1951, 496). Men were asked about their male associates and women were queried about their female friends. Sixteen percent of men included "politics and government" among the top three subjects discussed with other males, as did eight percent of women. Given the poll's timing, it is not surprising that 73 percent of men listed "war" among the top three topics they spoke about, as did 48 percent of women. Interestingly, however, women were slightly more likely than men to list "the 
draft" as one of the top three subjects they spoke about (12 v. $8 \%)$. All-inall, public affairs were among the most frequently mentioned subjects of conversations among men and women, although there were some interesting gender-based differences in the topics one discussed with persons of the same sex.

Since the Gallup poll was taken only 11 months before Pearl Harbor, these figures undoubtedly exaggerate Americans' tendency to talk about politics. What of political conversations in a time of "normalcy"? The Five Nation Study's American data show that, although only 24 percent of the Eisenhower era public said they never talked about politics, most people were only occasional political conversationalists. Half the public said they only talked politics from "time to time," while 11 percent said they engaged in political talk only once a week. Only one-eighth of the public claimed to talk about politics "nearly every day." Since these data were gathered in March, 1960, just as the presidential campaign was beginning, they may give a good sense of political conversations' frequency in the "off-season."

Part of the problem facing students of political conversations is paucity of comparable data over an extended period. The longest time span covered by an identical question is 40 years. The National Election Studies have asked people whether they engaged in proselytizing during campaigns since 1952. The data reveal that roughly a third of the public report proselytizing during a presidential election, and about one-fifth do so in off-years.

There is a problem with the oldest NES question about political discussion: Americans have an aversion to trying to "coerce" another's vote. An old cultural norm encourages one to make up her/his mind unassisted. Hence, the original NES question under-estimates the frequency of engaging in political conversations.

We need an item plumbing engagement in political conversations in general that has been asked several times. Fortunately, the NES has asked three questions on several occasions, but not before the mid-1980s. One item, asking "[d]o you ever discuss politics with your family and friends," appeared on the 1984, 1986, 1990, and 1992 National Election Studies. ${ }^{3}$ It shows that 67-71 percent of the public say they have "ever" talked politics to family and friends. That looks like a garrulous public. The problem is that "ever" can be a very long time.

When the NES follows this item with "[h]ow often do you discuss politics with your family and friends," six to nine percent say "every day," 10-12 percent report three or four times a week, 23-31 percent say "less often than that," and 29-33 percent admit they "never" talk about politics with family and friends. Once again, however, the lack of a relatively specific time frame confounds interpretation of the data. 
There is an item that better delineates the time frame of talking about politics, one that has been asked on each NES since 1984. The NES asked, "[h]ow many days last week did you talk about politics with your family and friends?" ${ }^{4}$ Even though people can misremember or misreport how many times they spoke about public affairs within the last week, identifying a specific, recent time frame probably reduces the amount of measurement error. For that reason, it will be the focus of much that follows.

Table 1 depicts how many times during the last seven days adult Americans reported speaking about politics with family and friends in 1984, 1986, 1988,1990 , and 1992. The fact that stands out most clearly is that large portions of the public claim to have eschewed talking about politics in recent days. The figures range from just under 50 percent (1984 and 1990) to roughly a third (1988 and 1992). Since the NES asked this question just a few weeks or days before or after a national election, these data probably depict the apogee of political talk in the U.S. today. Americans have but a lukewarm interest in public affairs (Bennett 1986) and, as we will see below, lack of psychological involvement affects the probability that public affairs crop up as a topic of discussions with family and friends.

That said, however, it appears that a majority engages in at least occasional conversations about politics. Moreover, if the data can be credited, the percentage rose slightly during the eight years covered in the table. We need data over a longer period to determine whether this constitutes a trend toward a more politically loquacious public.

\section{Table 1. How Many Days Last Week Americans Discussed Politics, 1984-1992}

\begin{tabular}{lcccccc}
\hline & 1984 & 1986 & 1988 & 1990 & 1992 & Total \\
\hline None & $42.9 \%$ & $45.6 \%$ & $36.0 \%$ & $48.1 \%$ & $33.9 \%$ & $41.2 \%$ \\
One & 14.0 & 13.8 & 12.8 & 12.7 & 14.2 & 13.5 \\
Two & 13.4 & 14.5 & 14.9 & 14.1 & 18.8 & 15.1 \\
Three & 9.4 & 9.5 & 10.9 & 9.1 & 11.5 & 10.1 \\
Four & 5.3 & 4.1 & 4.7 & 5.1 & 7.7 & 5.4 \\
Five & 2.1 & 2.8 & 4.2 & 1.8 & 2.5 & 2.6 \\
Six & 0.7 & 0.7 & 0.7 & 0.9 & 0.9 & 0.8 \\
Seven & 12.3 & 8.9 & 15.8 & 8.2 & 10.5 & 11.1 \\
Total & $100 \%$ & $100 \%$ & $100 \%$ & $100 \%$ & $100 \%$ & $100 \%$ \\
$\overline{\bar{X}}=$ & 1.91 & 1.68 & 2.30 & 1.61 & 2.09 & 1.92 \\
$\mathrm{~s}=$ & 2.35 & 2.17 & 2.49 & 2.13 & 2.22 & 2.29 \\
$(\mathrm{~N})$ & $(2,247)$ & $(2,158)$ & $(2,020)$ & $(1,981)$ & $(2,244)$ & $(10,650)$
\end{tabular}

Source: University of Michigan's Center for Political Studies' 1984-1992 National Election Studies. 
A third feature of the data is absence of a strong relationship between the frequency of engaging in political talk and the type of election year from which the data come. Although there is, as would be expected, slightly more talk in the presidential years of 1988 and 1992 than during the off-year contests of 1986 and 1990, 1984's figures are virtually the same as those from the two non-presidential years. Apparently the excitement generated by a presidential contest does not conduce an explosion of political discussion compared to off-year elections.

Table 1 has much to interest the student of political discussions, but it does not tell us several things we need to know. Is talking about politics part of a broader repertoire of political action, or does it constitute a distinct mode of involvement in politics? With whom do citizens discuss politics? Why don't people talk about politics? What affects the probability that one will engage in political conversations? These topics are taken up in the next sections.

\section{Is Talking about Politics a Distinct Mode of Political Action?}

To determine if political talk is a distinct mode of political participation, we performed a principal components (PC) analysis of 13 items that were asked on the 1967 Political Participation in America Study and the 1987 GSS. There were two questions about turnout in recent national elections, frequency of voting in local elections, membership in political organizations, donating money to a political party, candidate, or cause, working with others to solve a community problem, forming a new group to deal with community problems, contacting local officials, contacting non-local officials, attending political meetings or rallies, working for a party or candidate during a campaign, trying to influence another person's vote, and the frequency of general political discussions.

PC analysis was employed because we were conducting an exploratory study of the factors undergirding the observed correlation matrix (Kim and Mueller 1978a, 1978b). We limited the number of extracted factors to those having eigenvalues of at least 1.0..$^{5}$ Since previous studies have identified multiple modes of political participation that are correlated (Verba and Nie 1972), the data were rotated to an oblique solution.

Table 2 depicts the results from the PC analysis of the 13 items from the 1987 GSS. $^{6}$ The most important fact for our purposes is that engaging in political discussions does not load on any of the underlying dimensions uncovered by the factor analysis at .40 , which is the commonly accepted minimum value for stipulating that a given item "loads" on an underlying factor. The highest (.38) occurs on the "General Political Activity" factor, 
Table 2. Principal Components Analysis of 13 Political Participation Variables, with Oblique Rotation

\begin{tabular}{|c|c|c|c|c|}
\hline Variable & $\begin{array}{c}\text { FACTOR \#1 } \\
\text { "General } \\
\text { Politics" }\end{array}$ & $\begin{array}{c}\text { FACTOR \#2 } \\
\text { "Voting" }\end{array}$ & $\begin{array}{c}\text { FACTOR \#3 } \\
\text { "Local/ } \\
\text { Contacting" }\end{array}$ & $\mathrm{h}^{2}$ \\
\hline Member of Political Club & .68 & - & - & .50 \\
\hline Proselytized in Election & .66 & - & - & .44 \\
\hline Worked in a Campaign & .71 & - & - & .53 \\
\hline Attended a Political Meeting & .71 & - & - & .52 \\
\hline Donated Money to Politics & .61 & - & - & .40 \\
\hline Voted in 1980 Election & - & -.84 & - & .71 \\
\hline Voted in 1984 Election & - & -.87 & - & .77 \\
\hline How Often Vote in Local Election & - & -.85 & - & .74 \\
\hline Contacted Local Official & - & - & -.73 & .55 \\
\hline Contacted Nonlocal Official & - & - & -.66 & .46 \\
\hline Joined Group for Local Problem & - & - & -.76 & .58 \\
\hline Helped Form Local Group & - & - & -.73 & .54 \\
\hline How Often Talks Politics & .38 & -.35 & -.20 & .20 \\
\hline Eigenvalue & 4.21 & 1.56 & 1.16 & \\
\hline Percent of Variance & 32.4 & 12.0 & 8.9 & \\
\hline \multicolumn{5}{|l|}{ Factor Correlations: } \\
\hline Factor \#1 & 1.00 & -.34 & -.40 & \\
\hline Factor \#2 & & 1.00 & .33 & \\
\hline Factor \#3 & $(\mathrm{N}=1,6$ & & 1.00 & \\
\hline
\end{tabular}

Source: University of Chicago's National Opinion Research Center's 1987 General Social Survey.

which includes acts such as membership in political organizations, donating money for political purposes, and several campaign activities, including proselytizing.

The 1987 GSS and the 1967 Political Participation in America Study show that talking about politics is a distinct mode of involvement in public affairs. Political discussions are clearly apart from "vertical" activities in which citizens seek to influence government. Talking about politics is also a different type of political activity than proselytizing during a campaign. The 1987 GSS shows the two activities are correlated at only $r=.23$, indicating they share only five percent of common variance. (The 1988 and 1992 National Election Studies also show a weak correlation between the influence attempts variable and report of how often one talked about politics during the last week $[\mathrm{r}=.32]$.) 
When scholars thought political activities formed a single hierarchy of involvement, ranging from those demanding minimal time, initiative, and effort-such as exposing oneself to political stimuli-to those demanding a great deal of each-such as holding public office-engaging in political conversations was labelled a "spectator" activity (Milbrath 1965, 18). Researchers now know that political participation is multifaceted (Verba and Nie 1972), although the number, nature, and relationships are disputed (cf. Verba and Nie 1972 with Barnes, Kaase, et al. 1979). We believe the 1987 and 1967 data confirm Resnick and Bennett's (1993) contention that there is a set of political activities best characterized as "horizontal," i.e., those in which citizens interact with other citizens rather than government elites, thereby partaking in the political life of their community. Talking about politics is one such "horizontal" political activity.

\section{Who Are the Political Talkmates?}

Lane (1965) provided the most comprehensive review of early behavioral research into political conversations. He relied largely on the Columbia University studies of the 1940 and 1948 elections (Berelson, Lazarsfeld and McPhee 1954; Lazarsfeld, Berelson, and Gaudet 1948). In the main, the early data suggested that most political conversations occur among family members and friends. Moreover, people tended to talk to like-minded persons. As MacKuen notes, "people like to talk with friends and do not care for disagreements" $(1990,62)$. When talk did occur among persons from different social strata, it tended to be initiated by the lower status individual. As we will see, things do not appear to have changed much since the 1940s (see also Huckfeldt and Sprague 1995).

The National Opinion Research Center's 1967 "Political Participation in America Study" asked about engaging in political conversations (Verba and Nie 1972). When NORC asked respondents, "with whom do you discuss" politics and public affairs, the data showed that the most likely political talkmate was a family member or personal friend. Co-workers are occasionally mentioned. Politics is seldom discussed outside the family or friendship relationships.

The best recent source of information about with whom Americans talk about politics is the 1987 GSS, which replicated several items asked on the 1967 Political Participation in America Study. The 1987 GSS also contained several questions which were part of a series plumbing social networks that had been on the 1985 GSS (see Burt 1984; Knoke 1990). Respondents were asked to identify up to six people with whom they spoke about important matters. Respondents were queried about how often they talked politics with 
the first three persons they named, each political conversationalist's partisanship, how close the respondent was to each, and the nature of the relationship.

The 1987 GSS indicates Americans are a garrulous people. Ninety-five percent of the sample mentioned at least one person with whom they talked about important matters. Nearly three-fifths listed three or more talkmates.

It also appears that politics is a frequent topic of discussion in the U.S. Eighty-seven percent of those who listed three persons with whom they spoke about important matters reported political discussions with at least one. Interestingly, those who spoke with three or more people about important matters were more likely than those with two or fewer conversation partners to talk about politics. Only about 13 percent said they never discussed politics when speaking to people they normally talked with about important matters. That figure is smaller than the numbers reported by the National Election Studies, but given the context of the GSS series, the two data sources can probably be reconciled.

The GSS asked people how often they talked about public affairs. The norm was from at least monthly to at least weekly which, again, fits patterns in NES data. Not surprisingly, perhaps, the more people GSS respondents spoke to in general, the more often they discussed politics.

Three-quarters of the respondents said they felt close to the first person they mentioned, primarily because this person was a family member and a friend (these categories are not mutually exclusive). Co-workers, group members, and neighbors were less frequently mentioned as someone with whom respondents talked about politics. Here, again, the GSS data resonate with those of NES. Although respondents did not report feeling as close to the second and third persons they identified as conversation partners, even so, they were likely to be family and/or friends. For example, 68 percent of the first political discussants were listed as a family member, as were 53 percent of the second and 49 percent of the third. Seventy-one percent of the first political talkmate was said to be a "friend"-recall that family members could also be listed as "friends"-as were 74 percent of the second and 75 percent of the third. There was a slight increase in the percentage of second and third political conversation partners who were co-workers, from 14 percent of the first political discussant to 19 percent of the third.

Studies of parents and their offspring have reported that substantial percentages of Americans are unaware of family members' partisanship (Jennings and Niemi 1974). Hence, it occasions no surprise to find that a substantial percentage of GSS respondents did not know the party affiliation of persons with whom they discussed public affairs. Interestingly, the more political conversation partners one reported, the less likely he/she was to 
know their partisan leanings. Among those who did recall their conversation partners' partisanship, the 1987 GSS shows that Americans are still likely to talk about politics with those who identify with the same party as they, just as they did in the 1940s.

In short, the 1987 GSS indicates that political conversations today follow basically the same patterns as those in the 1940s. They also dovetail nicely with the 1984 South Bend study (Huckfeldt and Sprague 1995). When they do engage political discussions, Americans speak mostly with those to whom they feel close-family and friends-and with whom they share a common partisan identity. Although there are exceptions (see Huckfeldt and Sprague 1995), political talk occurs mostly within rather than across partisan lines, and within family and friendship ties. To some extent, asking people to mention people with whom they discuss "important" matters influenced the likely range of political conversation partners, but probably not significantly so, for the GSS data largely confirm NES data. ${ }^{7}$

Like religion, politics is not a likely topic when Americans speak with someone they do not know well (see MacKuen 1990). Indeed, the 1967 Political Participation in America Study and 1987 GSS show that Americans report that "public affairs and politics" are seldom discussed in groups to which they belong. Ironically, the cultural norm that politics is a private matter means that public affairs conversations are largely taboo in public.

\section{What Inhibits Talking about Politics?}

Why do Americans seldom talk about politics outside the family or among friends? This issue has rarely been plumbed by survey researchers. We have to go back to the American data from the Five Nation Study (Almond and Verba 1963). Although we wish there were more recent data, given the constancy in patterns reported thus far, it is likely that things have not changed much since the twilight of the Eisenhower era.

Almond and Verba asked their respondents if there were some people with whom they would not discuss political and governmental affairs, and if so, how many they were. Twenty-nine percent of the public claimed there were "no restrictions" because they "can talk about politics to anyone." Still, nearly 70 percent of the public admitted that there were at least some people with whom they would not discuss politics.

When Almond and Verba then asked why they avoided political discussions, the modal response among Americans (34\%) was that it was unpleasant or disturbed personal relationships. A quarter said that talking about politics was useless because other people had already made up their minds or were biased. Twelve percent said they avoided talking about politics 
because they themselves were too ignorant. Eleven percent feared being misquoted. Other reasons were given by small percentages.

We now know how frequently political conversations are reported in the U.S., with whom Americans talk about politics, and why some people avoid political discussions. The next section explores why Americans talk about politics.

\section{A Multivariate Analysis of Political Talk}

Given the paucity of empirical research, little is known about the factors affecting the likelihood that someone will engage in political conversations. Based on early behavioral studies of voting behavior, Lane (1965) boiled the factors that affect the tendency to talk about politics down to two: (1) motivation stemming from partisanship and general psychological involvement in public affairs, and (2) opportunity, which is affected by one's location in and contact with the social world. Milbrath's (1965) compendium generally dovetails with Lane's.

What follows is an assay of the factors that affect the frequency of talking about politics in the U.S. between 1984 and 1992. The dependent variable is the respondent's report of whether he or she talked about public affairs in the previous seven days. The 1984-1992 National Election Studies were pooled to produce a dataset with 10,960 cases. Pooling the National Election Studies has advantages in addition to the large number of cases, most important of which is indicating how much the type of election yearpresidential or off-year-affects the probability of political talk. One drawback to this procedure is that only those independent variables that were asked in identical fashion on every NES between 1984 and 1992 could be included as predictors in the estimated model.

Fortunately, as the data in Table 3 show, the National Election Studies contain a rich array of factors known to affect other modes of political participation, and that ought to influence how often people talk about politics. Table 3 depicts the results of a logit model in which 14 independent variables: the type of election year, age, race, gender, intelligence, martial status, education, family income, strength of partisanship, strength of ideology, concern about how the election came out, psychological involvement in public affairs, and reliance on newspaper and TV coverage of the campaign ${ }^{8}$ were used to predict the probability of talking about politics during the last week.)

The model being estimated in Table 3 assumes that several factors affect the probability that one will talk about politics. Lane (1965) argued that opportunity and motivation have an important impact on the probability 


\section{Table 3. Logit Analysis of Whether R Talked Politics in the Last Week on 14 Predictors}

\begin{tabular}{lccccr}
\hline Variable & $\mathrm{b}$ & s.e.b & Wald & $\mathrm{R}$ & Exp(B) \\
\hline Type of Election Year & .21 & .06 & $14.42 * * *$ & .03 & 1.23 \\
Gender & .02 & .05 & 0.14 & .00 & .98 \\
Race & .07 & .08 & 0.69 & .00 & 1.07 \\
Age & -.02 & .002 & $106.65 * * *$ & -.10 & .98 \\
Intelligence & .22 & .04 & $25.38 * * *$ & .05 & 1.25 \\
Marital Status & .19 & .06 & $11.37 * * *$ & .03 & 1.21 \\
Education & .08 & .01 & $38.27 * * *$ & .06 & 1.08 \\
Family Income & .005 & .001 & $11.88 * * *$ & .03 & 1.01 \\
Strength of Partisanship & .01 & .03 & 0.18 & .00 & 1.01 \\
Strength of Ideology & .13 & .02 & $30.32 * * *$ & .05 & 1.14 \\
Care Which Party Wins Election & .29 & .06 & $24.34 * * *$ & .05 & 1.33 \\
Political Apathy Scale & .37 & .02 & $534.97 * * *$ & .22 & 1.45 \\
Reliance on Newspapers & .07 & .02 & $9.88 * *$ & .03 & 1.07 \\
Reliance on Television & .08 & .02 & $12.91 * * *$ & .03 & 1.09 \\
Constant & -3.96 & .21 & $357.97 * * *$ & &
\end{tabular}

$$
\begin{gathered}
\text { Key: } \quad * p=.05 * * p=.01 \quad * * * p=.001 \\
-2 \text { LLR }=2,169.36 \mathrm{df}=14 \mathrm{p}=<.001
\end{gathered}
$$$$
\text { Pseudo } \mathrm{R}^{2}=.20
$$

$$
\begin{aligned}
& \text { Reduction of Error (ROE) }=29.85 \% \\
& \qquad(\mathrm{~N}=8,128)
\end{aligned}
$$

Source: University of Michigan's Center for Political Studies' pooled 1984-1992 National Election Studies.

that people will engage in political discussions (see also Sniderman 1975; Luskin 1990). "Opportunity" is affected by one's location in the social structure which, in turn, is shaped by factors such as gender, race, age, marital status, education, and family income. ${ }^{9}$ Those with more intelligence should be better able to talk about remote topics such as politics than those low in cognitive ability. Several variables affect motivation to talk about politics: education, strength of partisanship, strength of ideology, concern about the election's outcome, and psychological involvement in public affairs. ${ }^{10}$ Reliance on newspaper and television accounts of campaigns should also influence the probability of engaging in political conversations, as the content of the mass media are often the grist for political speech. Another factor that should affect talking about politics is whether the data come from a "high stimulus" presidential election or a "low stimulus" off-year election (Campbell 1966). The latter variable taps the political climate, which should also affect the likelihood that people will discuss politics. 
Ordinarily, when the dependent variable is a report of how many days one discussed politics in the preceding week, one might expect to see an OLS regression model. However, a combination of the dependent variable's limited range (0-7) and, more important, the extreme skew of responses (an average of $39 \%$ of the cases in the zero category), militated against OLS regression. Rather, we estimated a logit model of whether or not respondents talked politics in the last week, coded 0 for those who said they had not, and 1 for those who reported talking on one or more days. Collapse of the dependent variable from 0-7 to 0-1 means a loss of precision, but that is out-weighed by greater confidence that the data meet the logit model's assumptions.

The data show that the probability that Americans talk about politics is affected by the political climate, cognitive ability, opportunity, and motivation. The type of election year, intelligence, education, family income, marital status, age, strength of ideology, concern about the election's outcome, general psychological involvement in public affairs, and reliance on the mass media for information about campaigns are statistically significant predictors of the probability that people talk about politics. On the other hand, gender, race, and strength of partisanship do not significantly affect whether or not one will engage in political talk.

There are some surprises in the table. The most important is that strength of partisanship is not a significant predictor of engaging in political conversations. Strength of partisanship is known to be a significant predictor of psychological involvement in public affairs (Bennett 1986), and of other modes of political participation. For example, when another logit model, identical to that in Table 3, was estimated on reported turnout, strength of partisanship was statistically significant (data not shown). The tendency for people to talk about politics with others of like partisan proclivities may inhibit the predictive power of this variable.

It is possible to use the coefficient estimates to calculate the probabilities that a respondent will report talking about politics in the last week, conditional on the values of one or more independent variables. Most independent variables were estimated to their respective median values while type of election year, education, and political interest were set at their low, median, and high values in order to calculate the probability of talking about politics in the last week. The results are depicted in Table 4.

The data show that all three variables - type of election year, education, and political interest affect the probability that people talk about politics. The effects are the same for blacks and whites, and men and women. The combination of low educational attainment and limited interest in public affairs severely reduces the probability that people engage in political 


\section{Table 4. Conditional Probabilities of Talking Politics in Last Week,} by Type of Election Year, Race, Gender, Education, \& Political Interest

\section{BLACK MaLes, OfF Year}

LT High School Graduate, Very Uninterested in Politics: $\quad .40$

High School Graduate, Somewhat Interested in Politics: $\quad .78$

College Graduate, Very Interested in Politics: 95

BlaCK FEMALES, OfF YEAR

LT High School Graduate, Very Uninterested in Politics: $\quad .41$

High School Graduate, Somewhat Interested in Politics: $\quad .78$

College Graduate, Very Interested in Politics: 96

\section{White MaLes, OFF YeAR}

LT High School Graduate, Very Uninterested in Politics:

High School Graduate, Somewhat Interested in Politics: $\quad .78$

College Graduate, Very Interested in Politics: 96

\section{White FEMALES, OFF YEAR}

LT High School Graduate, Very Uninterested in Politics: $\quad .41$

High School Graduate, Somewhat Interested in Politics: $\quad .79$

College Graduate, Very Interested in Politics: 96

\section{Black Males, Presidential Year}

LT High School Graduate, Very Uninterested in Politics: $\quad .45$

High School Graduate, Somewhat Interested in Politics: $\quad .81$

College Graduate, Very Interested in Politics: 96

\section{Black Females, Presidential Year}

LT High School Graduate, Very Uninterested in Politics: $\quad .46$

High School Graduate, Somewhat Interested in Politics: $\quad .81$

College Graduate, Very Interested in Politics: 96

White Males, Presidential Year

LT High School Graduate, Very Uninterested in Politics: $\quad .46$

High School Graduate, Somewhat Interested in Politics: $\quad .82$

College Graduate, Very Interested in Politics: 96

White Females, PRESidentIAL YeAR

LT High School Graduate, Very Uninterested in Politics: $\quad .37$

High School Graduate, Somewhat Interested in Politics: $\quad .82$

College Graduate, Very Interested in Politics: $\quad .97$

Source: Pooled 1984-1992 National Election Studies. 
discussions. On the other hand, among the well educated who are also especially interested in politics, political talk is virtually universal. The difference in the probability that people discuss politics is greatest between presidential and off-years among those with low educational attainment and political interest, and least among college graduates who are very interested in public affairs.

How well do the data fit the model? One problem with logit models is lack of consensus on an indicator of model fit. A number of scholars have proposed using "Pseudo $\mathrm{R}^{2}$ " which purportedly has properties akin to the traditional $\mathrm{R}^{2}$ from OLS regression (see DeMaris 1992; Hagle and Mitchell 1992; Hosmer and Lemeshow 1989). However, they disagree over how best to calculate it. We report the version recommended by DeMaris (1992) and Hosmer and Lemeshow (1989). In addition, we also follow Hagle and Mitchell's (1992) suggestion to report the Log-Likelihood Ratio and the Reduction-of-Error (ROE) statistics. As they note $(1992,781)$, both statistics measure "a model's improvement over a selected baseline, rather than general model performance."

At bottom, what the three indicators suggest is that we have a fairly good fit. The Log-Likelihood Ratio is statistically significant, and the predictors included in the model produce a Pseudo $\mathrm{R}^{2}$ of $.20 .{ }^{11}$ By way of comparison, an identical logit model estimated on reported turnout resulted in a Pseudo $\mathrm{R}^{2}$ of .30 (data not shown), which is on a par with that in Table 3. In all likelihood, better measures of opportunity, motivation, etc., and a better understanding of the factors that affect talking about politics will lead to improved models in the future. Still, based on what secondary analysts are accustomed to seeing when multivariate models are fit to survey data, the model depicted in Table 3 is acceptable.

\section{Summary and Conclusions}

Our goal has been to explore political conversations among American citizens, a topic that has been given short shrift by empirical political science, despite its importance in normative democratic theory. We agree with theorists such as Aristotle, J.S. Mill, and John Dewey that talking about politics is a fundamental means by which citizens take part in the political life of their community and nation. We also believe that by focusing on this important mode of "horizontal" participation in public affairs, we can take a small but important step toward connecting empirical research to classical notions of democracy, which an early generation of behavioral researchers saw as a laudable goal. 
Drawing on pooled National Election Studies between 1984 and 1992, we learn that, albeit not ubiquitous, talking about politics is one of the most "popular" modes of citizen participation in the U.S. More than half the adult population report taking part in a recent political conversation and, although most Americans are only "occasional" conversationalists, fewer than a third claim to eschew political talk. Furthermore, if NES data can be credited, the typical citizen will engage in nearly 2,000 political conversations over a four-year period, compared to voting less than a dozen times during the same period (Boyd 1981; Sigelman et al. 1985). Yet, despite the vastly greater number of political conversations than votes cast during a given time period, scholars know far more about the causes and consequences of voting than of talking about politics.

Focusing on citizens talking about politics with other citizens provides a useful corrective to the characterization of political involvement as anemic and stunted that one frequently encounters in empirical studies of political participation in the U.S. In a stinging criticism of early empirical characterizations of American political behavior, Jack Walker $(1966,289)$ wrote that

[t]he most unsatisfactory element in the [elitist] theory [of democracy] is its concept of the passive, apolitical, common man who pays allegiance to his governors and to the sideshow of politics while remaining primarily concerned with his private life ... or the demands of his job.

The discovery that most Americans engage in political conversations does not, in itself, refute claims that the typical American is a passive lump of clay to be worked upon by her or his governors, but it raises a cautionary flag: there may be more civic involvement than scholars have realized. At the very least, we need to cast a wider net if we are to have a full understanding of how Americans take part in public affairs.

Another thing NES data tell us is that, although many of the same factors that shape the likelihood that citizens engage in other modes of political participation also affect the probability that they talk about politics, some predictors of other types of political action are not significant predictors of talking about politics. In addition, some factors usually ignored in participation studies shape the probability that Americans talk about politics.

We have also learned that Americans tend to talk about politics with family and friends, and that most political conversations go on between likeminded souls. In this sense, early behavioral data on political conversations are confirmed, despite the passage of several decades.

There is, however, much yet to learn about political discussions among democratic citizens. For example, do people still refrain from talking about politics for the same reasons given back in the twilight of the Eisenhower 
era? Much has changed in American politics since 1960, and in spite of seeming continuities in the data on political conversations, one is hard pressed to believe that today's Americans would give essentially the same reasons for eschewing political talk as their Eisenhower-era counterparts.

We also need to determine how much the frequency of political discussions changes over the course of a campaign. For example, although it seemed reasonable to assume that the probability of talking about politics would increase as election-day neared, data from the 1984, 1988, and 1992 National Election Studies showed that the point at which respondents were interviewed-measured in terms of how many weeks before the election the interview occurred-was not a statistically significant predictor of engaging in political talk. Still, it is likely that political discussions wax and wane during an election season-peaking after an important event such as a debate and ebbing at other times. We need more work on this question.

Another unknown is what talking about politics does for citizens and the political community. Democratic theorists have listed a number of salubrious outcomes when citizens talk about politics. Would an empirical investigation confirm these expectations? That is the topic for another study.

\section{NOTES}

A revised version of a paper prepared for delivery at the Midwest Political Science Association's Annual Meeting, Chicago, Illinois, April 14-16, 1994. We are indebted to M. Margaret Conway, of the University of Florida, Stephen Esquith, of Michigan State University, Charles D. Hadley, Christine L. Day, and three anonymous reviewers for The American Review of Politics for helpful comments and suggestions.

${ }^{1}$ There are, of course, exceptions (e.g., Crigler and Jensen 1991; Gamson 1992; MacKuen 1990). The corpus based on a 1984 survey of South Bend, Indiana residents and their talkmates is extremely important (Huckfeldt and Sprague 1995; Kenny 1992, 1993a, 1993b).

${ }^{2}$ The SRC/CPS and NORC data sets were released by the Inter-University Consortium for Political and Social Research to the University of Cincinnati's Institute for Policy Studies. We are responsible for all analyses and interpretations.

${ }^{3}$ People may have very different things in mind when they report "discussing politics" with family and friends. Some conversations may be about candidates and elections. Others center on general topics like "crime," "corrupt politicians," or "the economy." A few, perhaps, would make Socrates and his interlocutors feel quite at home. Unfortunately, with the data at hand, we cannot specify what people have in mind as they respond to these questions.

${ }^{4}$ One problem with this, and other questions about discussing "politics" or "public affairs" is these are, ultimately, ambiguous terms. Some people may not think they are engaging in "political" discussions when they discuss some topic touching on government 
or public affairs. Therefore, data on how frequently Americans engage in political discussions should be seen as approximate estimates.

${ }^{5} \mathrm{~A}$ maximum likelihood (ML) factor analysis of the 1987 data produced a chisquare/degrees of freedom ratio of 4.84 , just below 5 , the figure usually set for a satisfactory solution. The chi-square/degrees of freedom ratio for a three-factor solution with the 1967 data was 7.72. The reason for the slightly higher ratio in the 1967 data, however, is that the analysis was performed on 2,979 cases, double the 1987 sample's size (see Kim and Mueller 1978b). Therefore, we believe the two ML factor analyses are virtually identical.

${ }^{6}$ To facilitate interpretation of the table, other than the political discussion item, factor loadings below .40 are not shown. Since the results from the 1967 data are virtually identical, they are not shown to save space.

${ }^{7}$ The GSS social network data show that respondents who list multiple discussion partners list family and friends first and non-intimates subsequently (Burt 1984). Had the 1987 GSS asked respondents to list more than three political discussants, it is possible that more persons outside family and friendship circles would have been listed. Still, the 1987 GSS shows that the percentage of political discussants who were "others" remained at about two percent from the first to the third political talkmate. Of course, it is always possible for non-intimates to have an impact on people's views and behavior (Granovetter 1973; Kenny 1993b).

${ }^{8}$ The type of election year is coded 0 for off-years and 1 for presidential years. Gender is a dichotomy, coded 0 for women and 1 for men. Race is also a dichotomy, coded 0 for African-Americans and 1 for whites. Age is coded as the actual year. "Intelligence" is indicated by the interviewer's estimate-which has been found to be valid (Luskin 1990)-and ranges from "very low" (1) to "very high" (5). Marital status is a dichotomy, coded 0 for "not married" and 1 for "married." Education is the number of years of formal schooling completed, and ranges from 0 to $17+$. Family income is recoded to the NES's category midpoint, and ranges from 1 (for $\$ 0-2,000$ ) to 145 (for $\$ 90,000$ and above). Strength of partisanship has five categories, ranging from apolitical/ other (1) to strong partisan (5). Strength of ideology also has five categories, ranging from "no interest/don't know" (1) to "extreme ideologue" (5). Concern about the election's outcome is a dichotomy, coded 0 (don't care) and 1 (care). Psychological involvement in public affairs is tapped by the Political Apathy Index (see Bennett 1986), which has eight categories ranging from "very apathetic" (2) to "very interested" (9). Reliance on newspapers and on television for information about the campaigns have five categories, ranging from "none" (1) to "a great deal" (5).

${ }^{9}$ Some might argue that opportunity ought to depend on employment status and occupation, since employment outside the home and type of work should affect the probability of engaging in political conversations. However, when a separate logit analysis was run with employment status measured as a dummy (not in the work force and working) and several occupation dummies (unskilled and semi-skilled, service worker, skilled worker, clerical and sales, professional employee, and business manager), none of the work-related variables was a statistically significant predictor. It might also be thought that persons with minor children in the home would have a greater opportunity to talk about public affairs than those without. However, we found that the number of infants under 5 years of age in the household, the number of children aged 6 to 9 , the 
number of preteens, and the number of teenagers were not significant predictors of the probability that a respondent would report a recent political conversation.

${ }^{10}$ When strength of partisanship, strength of ideology, concern about the election's outcome, and the Political Apathy Index were included in a PC analysis, each loaded on the same dimension above .60 . In short, all four indicators tap the same underlying construct.

${ }^{11}$ Students of logit models argue that Pseudo $\mathrm{R}^{2}$ typically under-estimates a model's predictive efficacy, because explanatory power is lost when the dependent variable is a binary variable (DeMaris 1992; Hagle and Mitchell 1992).

\section{REFERENCES}

Almond, Gabriel A., and Sidney Verba. 1963. The Civic Culture. Princeton: Princeton University Press.

Aristotle. 1988. The Politics, ed. Stephen Everson. Cambridge: Cambridge University Press.

Barnes, Samuel, Max Kaase, et al. 1979. Political Action: Mass Participation in Five Western Democracies. Beverly Hills: SAGE.

Bennett, Stephen E. 1986. Apathy in America, 1960-1984. Dobbs Ferry, NY: Transnational Publishers.

Berelson, Bernard R., Paul M. Lazarsfeld, and William N. McPhee. 1954. Voting. Chicago: University of Chicago Press.

Boyd, Richard W. 1981. Decline of U.S. Voter Turnout: Structural Explanations. American Politics Quarterly 9:133-59.

Burt, Ronald S. 1984. Network Items and the General Social Survey. Social Networks 6:293-339.

Campbell, Angus. 1966. Surge and Decline: A Study of Electoral Change. In Angus Campbell, Philip E. Converse, Warren E. Miller, and Donald E. Stokes, Elections and the Political Order. New York: Wiley.

Cantril, Hadley D., and Mildred Strunk. 1951. Public Opinion 1935-1946. Princeton: Princeton University Press.

Conway, M. Margaret. 1991. The Study of Political Participation: Past, Present, and Future. In William J. Crotty, ed., Political Science: Looking to the Future. Volume 3. Evanston, IL: Northwestern University Press.

Crigler, Ann N., and Klau Bruhn Jensen. 1991. Discourses on Politics: Talking about Public Issues in the United States and Denmark. In Peter Dahlgren and Colin Sparks, eds., Communication and Citizenship. London: Routledge.

DeMaris, Alfred. 1992. Logit Modeling: Practical Applications. SAGE University Paper series on Quantitative Applications in the Social Sciences, series no. 07-086. Newbury Park, CA: SAGE.

Denk, Charles E., and Steven J. Finkel. 1992. The Aggregate Impact of Explanatory Variables in Logit and Linear Probability Models. American Journal of Political Science 36:785-804.

Dewey, John. 1927. The Public and Its Problems. New York: Holt.

Dryzek, John S. 1988. The Mismeasure of Political Man. Journal of Politics 50:705-25. 
Farr, James. 1993. Framing Democratic Discussion. In George E. Marcus and Russell L. Hanson, eds., Reconsidering the Democratic Public. University Park: Pennsylvania State University Press.

Gamson, William A. 1992. Talking Politics. Cambridge: Cambridge University Press. Granovetter, Mark. 1973. The Strength of Weak Ties. American Journal of Sociology 78:1360-80.

Hagle, Timothy M., and Glenn E. Mitchell II. 1992. Goodness-of-Fit Measures for Probit and Logit. American Journal of Political Science 36:762-84.

Hosmer, David W., and Stanley Lemeshow. 1989. Applied Logistic Regression. New York: Wiley.

Huckfeldt, Robert, and John Sprague. 1995. Citizen, Politics, and Social Communication. Cambridge: Cambridge University Press.

Kenny, Christopher B. 1992. Political Participation and Effects from the Social Environment. American Journal of Political Science 36:259-67.

. 1993a. The Microenvironment of Political Participation. American Politics Quarterly 21:223-38.

1993b. Social Influence and Opinion on Abortion. Social Science Quarterly 74:560-74.

Kim, Jae-On, and Charles W. Mueller. 1978a. Introduction to Factor Analysis: What It Is and How To Do It. SAGE University Paper series on Quantitative Applications in the Social Sciences, series no. 07-013. Beverly Hills: SAGE.

1978b. Factor Analysis: Statistical Methods and Practical Issues. SAGE University Paper series on Quantitative Applications in the Social Sciences, series no. 07-014. Beverly Hills: SAGE.

Kinder, Donald R., and Don Herzog. 1993. Democratic Discussion. In George E. Marcus and Russell L. Hanson, eds., Reconsidering the Democratic Public. University Park: Pennsylvania State University Press.

Knoke, David. 1990. Political Networks: The Structural Perspective. Cambridge: Cambridge University Press.

Lane, Robert E. 1965. Political Life: Why and How People Get Involved in Politics, rev. ed. New York: The Free Press.

Lazarsfeld, Paul, Bernard Berelson, and Hazel Gaudet. 1948. The People's Choice, 3rd ed. New York: Columbia University Press.

Luskin, Robert C. 1990. Explaining Political Sophistication. Political Behavior 12:33161.

MacKuen, Michael. 1990. Speaking of Politics: Individual Conversational Choice, Public Opinion, and the Prospects of Deliberative Democracy. In John A. Ferejohn and James H. Kuklinski, eds., Information and Democratic Processes. Urbana: University of Illinois Press.

Mansbridge, Jane J. 1983. Beyond Adversary Democracy, rev. ed. Chicago: University of Chicago Press.

Milbrath, Lester W. 1965. Political Participation. Chicago: Rand McNally.

Mill, John Stuart. [1861] 1958. Considerations on Representative Government, ed. Currin v. Shields. Indianapolis: Bobbs-Merrill.

. [1859] 1978. On Liberty, ed. Elizabeth Rapaport. Indianapolis: Hackett Publishing Co. 
Parry, Geraint, George Moyser, and Neil Day. 1992. Political Participation and Democracy in Britain. Cambridge: Cambridge University Press.

Resnick, David, and Stephen E. Bennett. 1993. Rethinking Political Participation. Paper presented at the annual meeting of the Midwest Political Science Association, Chicago, April 13-15.

Sigelman, Lee, Philip W. Roeder, Malcolm E. Jewell, and Michael A. Baer. 1985. Voting and Non-voting: A Multi-Election Perspective. American Journal of Political Science 29:749-65.

Sniderman, Paul M. 1975. Personality and Democratic Politics. Berkeley: University of California Press.

Verba, Sidney, and Norman H. Nie. 1972. Political Participation in America: Political Democracy and Social Equality. New York: Harper \& Row.

Walker, Jack L. 1966. A Critique of the Elitist Theory of Democracy. American Political Science Review 60:285-95. 